\title{
Ignacio Ellacuría, el hombre y el cristiano. "Bajar de la cruz al pueblo crucificado" (II)
}

\author{
Jon Sobrino \\ Centro de Reflexión Teológica, \\ San Salvador.
}

Segunda parte: el cristiano

\section{La incidencia histórica del cristianismo}

Todo lo que hemos mencionado - servicio, justicia, profecía, utopía etc.son ya $\longrightarrow$ pueden ser- realidades claramente cristianas. Pero, además, Ellacuría con frecuencia hablaba explícilamente sobre lo cristiano y como cristiano, y lo hacía no sólo cuando escribía teología, sino en conversaciones, en discursos sobre la realidad del país y en relación a ideologías como la del marxismo. Lo cristiano, pues, estuvo muy presente en él. Veamos en qué consiste.

\subsection{Lo cristiano como realidad configuradora de la persona}

Para adentrarnos en el Ellacuría cristiano, quisiera comenzar con una constatación que me llamaba la atención. Ellacuría no era dado, en absoluto, a lenguaje piadosista, ni hablaba con facilidad sobre su fe personal. No era, pues, de aquellos que según el evangelio andan diciendo a cada rato "Señor, Señor", pero sí era de los que van a trabajar al campo a hacer la voluntad de Dios. Y tampoco era dado a lenguaje lírico y paradojico, alejado de la racionalidad, sino más bien a todo lo contrario.

Pues bien, ese Ellacuría usaba con frecuencia expresiones como "lo cristiano es esto o aquello...", "los cristianos deben ser los primeros en...", "pero lo más cristiano es...". A veces hacía también afirmaciones claramente utópicoproféticas, con poca racionalidad aparente, como hemos visto, pero que son afirmaciones centrales en la fe cristiana: "más feliz es el que da que el que recibe", "el siervo trae salvación", "se puede vivir como resucitados ya en la 
historia", etc. Todo esto significa que el cristianismo fue para Ellacuría cosa muy real y algo que desde sus elementos históricos y también desde sus elemenlos transcendentes tiene la capacidad de configurar la persona, $e$, indirectamente, también a pueblos y sociedades. Por eso, veamos que es lo que entendra por $l o$ cristiano, expresión que va más allá de la mera doctrina y rutina, y que fue existencialmente importante para él.

a) Lo cristiano es algo real que consiste en una forma globalizante de ser, de ver, de actuar, de esperar y de celebrar. Eso aparece en personas - y análogamente en grupos humanos- y en sociedades. Lo primero se expresa en el seguimiento de Jesús y en la configuración de seres humanos a su imagen. Lo segundo, en una sociedad configurada según el ideal del reino de Dios.

b) Lo cristiano concreto que influyó existencialmente en Ellacuría tiene como principio configurador e impulsador la tradición originada en Jesús de Nazaret, historizada y vivida comunitariamente en el pueblo de Dios a lo largo de los siglos -bajo el impulso del Espíritu- y revitalizada por los mejores cristianos, los santos, un san Ignacio de Loyola o un san Francisco de Asís, un Monseñor Romero o un Padre Arrupe, por citar algunos que él solía mencionar. Esto no significa que Ellacuría no aceplase -y aun alabase algunas de ellasmuchas otras cosas de lo cristiano: tradición dogmática, vida litúrgica y sacramental, institución eclesial etc., pero lo fundamental lo veĺa él en Jesús y en la tradición de Jesús que se ha mantenido a lo largo de la historia. Jesús y su seguimiento, pues, no eran para él todo lo cristiano, pero sí fueron existencialmente lo fundamental.

c) Lo cristiano, por último, tiene identidad propia y características específicas, aunque Ellacurfa encontraba en él cosas comunes con elementos de la modernidad, de movimientos populares, del marxismo...1. Esto lo recalcaba teóricamente no por purismos ortodoxos, sino porque crela que esa identidad era real y que mantenerla era beneficioso para todos. Asf, dicho en términos operativos, solfa decir que el cristiano no tiene por qué tener complejos de inferioridad si realmente pone a producir su fe en la línea del evangelio, aunque tampoco debiera tener complejo de superioridad, sobre todo aquI en América Latina, cuando en los inicios de los movimientos de liberación el compromiso y la eticidad del marxismo "suscitó entre los cristianos un cierto sonrojo por lo que suponfa de olvido de algo esencial a la fe y un cierto complejo de inferioridad" 2 .

Sobre esta identidad y especificidad de lo cristiano Ellacurfa reflexionó y escribió abundantemente -y pronto esperamos publicar en UCA Editores sus escritos teológicos en tres volúmenes. En ellos analiza una gran variedad de temas, como el reino de Dios, el Jesús histórico, la Iglesia de los pobres, el seguimiento de Cristo, la espiritualidad, las comunidades de base y muchos otros. 
No los vamos a analizar ahora, sino que más bien nos vamos a fijar en cómo lo cristiano le configuró personalmente, lo cual se nota con claridad en su visión y toma de postura ante algunas importantes realidades negativas y otras positivas de la historia; en el lenguaje de la tradición cristiana, el mysterium iniquitatis y el mysterium salusis. De esa forma, aunque sea de forma indirecta, podremos acceder al Ellacuría cristiano. $Y$ es ésta una forma más adecuada, pensamos, para llegar hasta su persona y no sólo el análisis de sus textos teológicos.

\subsection{El mysterium iniquitatis}

\subsubsection{El pecado}

Ellacuría estaba convencido de que en el mundo no sólo hay limitaciones, intentos fallidos de la evolución, fracasos -expresiones lodas útiles para constatar la negatividad de la historia-, sino que usó repetida y radicalmente la expresión pecado, lo cual nos introduce en su visión cristiana de la negatividad de la historia. Veámoslo en tres puntos.

a) Al usar la terminología cristiana de pecado, Ellacurja sitúa la negatividad de la historia en un contexto de ultimidad. Con ese término la declara algo radical por estar enraizada en la historia, como no lo hacen otras formas de pensar, y con ello también, sub specie contrarii apunta a lo teologal. La encarnación, solfa decir, es el devenir carne del Hijo en la historia, citando a Rahner, pero - añadía como cosa fundamental- en una historia de pecado.

b) Además de insistir en la ultimidad del pecado, insistla también en que el pecado debe ser no sólo perdonado en la subjetividad del pecador, sino erradicado en la historia, con lo cual recogla tanto la tradición evangélica de acogida al pecador como la tradición profética de erradicarlo. Esto último es lo que hace necesario luchar contra el pecado - superar la alienación, trastocar las estructuras etc., en el lenguaje de la modemidad-, todo lo cual implica hacer uso de algún tipo de fuerza para - desde fuera- erradicar el pecado. En esto Ellacurfa no era especialmente original ni expresaba nada específicamente cristiano, aunque con ello superaba falsos pacifismos aparentemente cristianos y recuperaba el carácter agonista de la fe -y en la práctica, mostró gran creatividad en propuestas concretas sobre cómo luchar contra el pecado.

c) Al insistir en la necesidad de luchar contra el pecado, Ellacuría superaba la postmodernidad y compartía la visión de la modemidad, pero a ello añadía algo que esta úllima suele ignorar o sobre lo que suele pasar muy a la ligera: para erradicar el pecado hay que cargar con el -lo cual es algo específicamente cristiano. En otras palabras, el pecado no sólo debe ser combatido desde fuera, sino también desde dentro cargando con él y estando dispuesto a ser triturado por él, lo cual no debe ser comprendido meramente como el necesario costo 
social que hay que pagar para que el progreso o una revolución tengan éxito. Esto es lo que Ellacuría aceplaba como algo específicamente cristiano. Indefensamente solía citar los cantos del siervo sufriente de Yahvé, quien, sucumbiendo él mismo al poder del pecado, lo erradica:

El siervo justificará a muchos porque cargó con los crimenes de ellos... El Señor mismo asume esta situación: carga sobre él todos nuestros crímenes... Sólo en un diff́cil acto de fe el cantor del siervo es capaz de descubrir lo que aparece como todo lo contrario a los ojos de la historia3.

Que esto no era palabrería piadosa se notaba claramente en cuán a menudo y con cuánta naturalidad repetía la idea de que hay que cargar con el peso del pecado. Recuerdo que el 19 sepliembre de 1989, en el discurso que pronunció con ocasión del doctorado honoris causa que la UCA otorgó al presidente Oscar Arias, en presencia tambiên del presidente Cristiani, del embajador norteamericano y de otros personajes de la política, Ellacuría —en medio de hondos análjsis políticos- dijo inesperadamente y con toda naturalidad las siguientes palabras:

Mucho ha sido el dolor y mucha la sangre derramada, pero ya el clásico teologumenon de nulla redemptio sine efussione sanguinis nos viene a recordar que la salvación y la liberación de los pueblos pasa por muy dolorosos sacrificios 4 .

Con estas palabras Ellacuría quería recordar, en directo, que los pasos hacia la paz no habran sido conseguidos śblo por personajes y gestiones políticas, sino que para ello hablan sido igual o más importantes el dolor y la sangre derramada del pueblo. Y en ese contexto -inesperadamente- se remontó a lo cristiano y citó la conocida sentencia: sin derramamiento de sangre no hay redención; en nuestra terminología, sin cargar con el pecado no se le erradica. Ellacuría no estaba sancionando ningún dolorismo ni masoquismo ni anselmianismo, sino que estaba expresando su honda convicción cristiana: para traer salvación hay que estar dispuestos a cargar con el pecado.

\subsubsection{La violencia}

Ellacurfa analizó también una de las formas históricas más graves en las que se expresa la negatividad: la violencia. Ante ella busc6 una definición adecuada: el uso injusto de la fuerza. La jerarquizó fundamentalmente de acuerdo a Medellín: violencia originante que toma dos formas, la injusticia estructural verdadera violencia institucionalizada - más la violencia represiva para mantenerla, y la violencia de respuesta, revolucionaria. Analizo la posible legitimidad o ilegitimidad de la violencia de respuesta y bajo qué condiciones, en lo cual siguió sustancialmente la doctrina de la teología tradicional. Además, como aporte suyo, insistio - y en eso sf fue realista - en "humanizar" la violencia, 
minimizándola y usando el principio de proporcionalidad en la respuesta. Sobre todo, trató de prevenirla antes del estallido y de erradicarla una vez que estallaras.

En todo esto, Ellacurfa reflexionó y actuó con la responsabilidad de todo ser humano, y también a este nivel dio importantes aportes, como hemos analizado en otra parte6. En resumen podemos decir que, Ellacuria, por un lado, no fue pacifista a ultranza, sobre todo una vez que ya había estallado el conflicto, sino que insisti6 en la absoluta necesidad de combatir la injusticia, pero, por otro, insistí también en el gran mal que la violencia es en sí misma, aun la que llega a ser legítima, y en los graves subproductos negativos que produce. Ante los fanáticos de la violencia y los que querfan hacer de ella una mística, decla que "la violencia es siempre un mal, mayor de lo que se piensa"7. Y en lenguaje gráfico al que era dado sobre todo en televisión, decĺa cosas como éstas: "sólo los pacifistas debieran hacer la guerra", para comunicar con cuánto cuidado hay que aceptar la violencia aun la legítima. "Con lágrimas tenemos que comunicar que hemos infligido tantas bajas al adversario", para comunicar cuán alejada debe estar la violencia de convertirse en mística.

Sin embargo, por lo que toca a este apartado, quiero insistir en que Ellacurfa también proponía y ofrecía algo específicamente cristiano ante la violencia, aun cuando ésta fuese legf́tima violencia de respuesta a la injusticia. Eso cristiano era una forma especiffica de luchar y la decisión de redimir la violencia. Esto es lo que escribio, pocos meses antes de ser asesinado él mismo.

Parecería que desde un punto de vista más cristiano, el de la perfección en el seguimiento del Jesús histórico, los cristianos reduplicativamente cristianos en su ser y en su actuar, siendo los primeros y más arriesgados en combatir toda forma de injusticia, no deberfan hacer uso de la violencia. No es que la violencia sea siempre y en todos los casos rechazable para un cristiano, pero el cristiano en cuanto tal no da ordinariamente su testimonio especffico a través de la violencia. No es tampoco que se quiera dejar el trabajo "sucio" a otros, mientras que el cristiano se queda entre los "puros" que no se ensucian las manos. Se trata más bien de dar de la manera más cabal y plena el testimonio de que la vida está sobre la muerte, de que el amor está sobre el odio. Tal actitud serfa aceptable y eficaz si es que ese mismo cristiano se atreviera hasta el martirio en la defensa de los más pobres y en el combate contra los opresores con el testimonio de su palabra y de su vidab.

Lo que Ellacuría afirma en este párrafo - cuya formulación le salió tortuosa por oscilar entre lo permitido a un cristiano y lo específicamente suyo- es que al cristiano le toca, como a todos, combatir y luchar contra toda forma de injusticia, pero que lo especificamente cristiano está (a) en usar medios que en sí mismos expresen la supremacía de la vida sobre la muerte, (b) en que ellos mismos, los cristianos, estén dispuestos a ser "los primeros y más arriesgados... 
hasta el martirio", con lo cual tendrán credibilidad ante los demás. A esto hay que añadir lo que ya hemos dicho antes: que carguen con la violencia y traten así de revertir su dinamismo mortifero, es decir, redimirla.

Con esta expresión, "redimir la violencia", se está expresando quizás lo más específicamente cristiano ante ella. Se trataría en esa redención de poner acontecimentos que no sólo detengan la espiral de la violencia sino que, en cuanto acontecimientos fundantes, erradiquen sus tíltimas raíces. En eso consiste el valor salvífico de cargar con la violencia injusta, $y$ al hacerlo indefensamente se eslá tratando también de redimir lo que la violencia tiene de hybris y aun de mística. Y quizás desde estas perspectiva pueda interpretarse también lo que la cruz de Jesús tiene de salvífico - como parece hacerlo Pablo- como acontecimiento que, en palabras metafóricas, deja que la violencia desahogue toda su fuerza contra Jesús hasta quedarse ella sin fuerza. Así puede revertirse, quizás, el dinamismo de la violencia.

\subsubsection{EI poder}

Digamos también una palabra sobre lo que Ellacuría pensaba acerca del poder. En forma personal y directa solía repetir cuán peligroso es el poder -incluyendo el de ser rector de la UCA, solía puntualizar. Para conseguirlo y mantenerlo, el poder suele ir acompañado de graves males físicos y morales, y su uso suele generar muchos otros males. Por ello, consideró el poder como mal, aunque inevitable, como mal menor necesitado siempre de redención histórica, lo cual significa racionalizar al máximo su ejercicio para minimizar sus subproductos negativos. Este juicio sobre el poder le vino de la observación histórica, pero también de la fe cristiana. Veamos el comentario que hizo al pasaje de las tentaciones de Jesús:

Es interesante subrayar la idea diabólica del poder y la gloria de los reinos de este mundo, sobre todo en la versión de Lucas, donde el evangelista subraya que le han sido entregados al diablo; es decir, no que en sí sean diabolicos sino que históricamente lo son?.

De ahl, también, su visión sobre el mundo de la política. Ellacuría no era en absoluto de talante y convicción anarquista, sino que - aceptando la necesidad e inevitabilidad de su existencia y su mayor o menor capacidad de hacer el bien-vio también en la política y en los partidos políticos una proclividad especffica a los males que provienen de buscar y detentar el poder. Por ello, con racionalidad histórica, pero en definitiva guiado por la utopla de lo cristiano, propició el trabajo de otro tipo de instituciones y organizaciones, como la Iglesia, la vida religiosa, las universidades, los sindicatos, los movimientos de base, etc., que, por su naturaleza, inciden más desde lo social que desde lo político, y buscó generar los valores que se basan en lo social: la verdad, la esperanza, la reconciliación, el sentido de comunidad y de celebración, la espiritualidad y el arte, los 
cuales, a su vez, pueden convertirse en fuerza social y, en este sentido, también en poder.

Y buscó esos valores más que los que se basan en lo político, pues éstos tienden a que el partido se anteponga al interés de las mayorías. En cualquier caso, Ellacurf́a vio el ámbito de lo social más consonante con las posibilidades humanizadoras de lo cristiano, y por eso animaba a los movimientos de base a mantenerse como tales y a no convertirse fácilmente en partido, pues su mayor aporte lo realizarían como movimientos:

Aquí no se niega el derecho y las ventajas que puedan darse en la constitución del frente político; lo que se pone en duda es el orden de prioridad: si la organización-base o el frente político. Pocas dudas caben de que los dinamismos de unas y otros, si no contradictorios pueden ser divergentes. $Y$ en todo caso, habrá que dar prioridad a las organzaciones-base y no al frente político... Lo social es más básico que lo político, aunque coyunturalmente lo político pueda primar sobre lo social 10.

En este modo de ver y de actuar ante lo negativo de la historia, el pecado, la violencia y el poder, se echa de ver cuán hondamente estaba influyuendo lo cristiano en Ellacuría.

\subsection{El mysterium salutis}

Acabamos de ver con qué hondura veía y juzgaba Ellacuría la negatividad de este mundo como mysterium iniquitatis al que hay que combatir y con el que hay que cargar para erradicarlo. Pero desde lo cristiano vera la realidad también como positividad, como mysterium salutis, que carga con nosotros. En este sentido, Ellacurfa me hace recordar una frase de Rahner en sus últimos años: "el evangelio es una pesada carga ligera que cuanto más la lleva uno más le lleva él a uno". Es decir, Ellacuría también vio en lo cristiano una realidad con capacidad para configurarnos ante lo positivo de la realidad.

\subsubsection{La esperanza de salvación}

Esto aparece ante todo en su esperanza de que, a pesar de la iniquidad, hay posiblidad de salvación y de salvación que se debe hacer realidad ya en la historia. Esa es una afirmación fundamental —utópica en el sentido en que hemos hablado antes, no en el de ingenuidad - posibilitada por lo cristiano y que nunca hay que darla por supuesta.

Ya desde el comienzo de su trabajo en El Salvador, Ellacuría insitio en la realidad de la salvación y acuño su conocida sentencia: "la historia de la salvación es una salvación en la historia"1l, con lo cual evidentemente querfa historizar, hacer real la salvación de Dios en el mundo. Pero lo que queremos recalcar ahora es su insistencia en la esperanza misma de que la salvación es 
posible, y su contribución a que esa esperanza de salvación se hiciese presente en el tratamiento de todos los temas teológicos, lo cual, por sencillo que parezca el decirlo, es ya una confesión de fe -0 al menos de esperanza-, pues en este mundo no es nada razonable la expectativa de salvación histórica, y menos para un Ellacuría nada ingenuo y que, por ello, no aceptaba la salvación que dogmática y mecánicamente, a derechas y a izquierdas, pronostican algunos. Las raíces de su esperanza de salvación, la decisión de trabajar y luchar por ella hasta el final, tenían otra savia: lo cristiano.

Es importante recordar que dos de sus artículos más fundamentales ya citados, "El pueblo crucificado", escrito originalmente en 1978, y "Utopía y profetismo", escrito en 1989, llevan como subtítulo "Ensayo de soteriología histórica", el primero, y "Un ensayo concreto de soteriología histórica", el segundo. El primer artículo sobre todo es notable desde el punto de vista de la salvación. Aceptar en serio que el pueblo crucificado trae algo de bueno a este mundo es todo menos evidente. Sin embargo, esa fue la fe de Ellacuría que le llevó a investigar en serio en qué sentido histórico ese pueblo crucificado aporta salvación. Esto lo desarrolló de diversas formas, mostrando cómo ese pueblo es "luz de las naciones", como se dice en Isaías 42,$6 ; 49,6$, e historizándolo para nuestro días como camino a la verdad y a la utopia, fuerza de conversión, llevador de otros en la fe...

Y su segundo artículo termina de forma programática -a la manera de testamento- con un canto a la Iglesia de los pobres que es la que Irae la salvación:

La Iglesia de los pobres se constituye en el nuevo cielo... La alimación utópica de una Iglesia como el cielo nuevo de una civilización de la pobreza es un reclamo irrecusable de los signos de los tiempos y de la dinánica soteriológica de la fe cristiana historizada en hombres nuevos, que siguen anunciando firmemente, aunque siempre a oscuras, un futuro siempre mayor, porque más allá de los sucesivos futuros históricos se avizora el Dios salvador, el Dios liberador 12.

Este dinamismo soteriológico, la esperanza que genera y la visión de la realidad que supone, como realidad siempre con posibilidades más allá de lo que nosotros podemos operar sobre ella, eso es esencial a lo cristiano. En su propia vida Ellacuría dio testimonio insigne de esa esperanza. Nunca dejo de trabajar por la salvación, ajustándose a la realidad, sí, pero sin ignorar la utopfa. Y eso, tan infrecuente, cuando se ve cuán pronto pactan algunos con las limitaciones de la realidad y olvidan la esperanza de que la salvación es posible, expresa muy bien su entraña cristiana

No por mera fidelidad a imperativos kantianos, sino por convicción crisliana y en último término por convicción de fe - "se avizora el Dios salvador", dice bellamemente-, trabajó hasta el final para que la salvacion histórica se hiciese 
realidad.

\subsubsection{La pobreza}

También en su visión de la pobreza se echa de ver el influjo específico de lo cristiano. Muchas veces repitió que según el cristianismo la riqueza es la gran tentación. Y así, un día dijo en televisión, sin que nadie lo esperara, que "los políticos, los militares y los sacerdotes debfan dejar sus puestos con menos dinero que con el que entraron", locura más que utopía, pero con lo que quería recalcar la perenne tentación de la riqueza y quiénes son los que más fácilmente pueden caer en ella, aunque sean ellos también los que más debieran servir al pueblo. Pero dejando de lado la anécdota, volvamos a la pobreza.

Al proponer como necesaria la civilización de la pobreza, Ellacuría afirma, por una parte, que es "una necesidad histórica", "más afín con lo que es la relación recursos mundiales-bienestar universal"13, pero argumenta también -indefensamente - con lo cristiano:

El tercer mundo se puede convertir en el lugar natural de la fe cristiana... Se vivirá así más fácilmente el espíritu evangélico, según el cual no hace falta tener mucho para ser mucho... Se entrarfa asl en una civilización de la pobreza plenamente coherente con la predicación de Jesús..., una civilización, abierta a lo transcendente y muy en especial a la forma cristiana de transcendencia tal como ésta se revela en Jesús de Nazaret que se igualó con los más pobres para hacer ver de modo nuevo la gloria de Dios'4.

Ellacurfa no fue pauperista, ni fue de los que quieren "repartir miseria", pero vio en la pobreza algo positivo, y ello le vino dado con la aceptación del evangelio. Es verdad que, hasta cierto punto, se pueden mostrar racionalmente los bienes de la pobreza, pero en definitiva el elogio de la pobreza es una locura evangélica, que, de hacerlo, se mantiene por sí misma, indefensa, y que los santos han mostrado como humanizadora.

También del evangelio - véase lo que dice sobre la pobreza y la riqueza el Magnificat $y$ las bienaventuranzas-malaventuranzas de Lucas- aprendió Ellacuría el dinamismo excluyente y duélico entre riqueza y pobreza, y el carácter de "principio" de cada una de ellas, que por su naturaleza lleva a todos los vicios una, y a todas las virtudes otra, lo que aprendió de los ejercicios espirituales de san Ignacio, especialmente al analizar la meditación de las dos banderasis.

Esa valoración cristiana de la pobreza se echa de ver, por último, en su distanciamiento del análisis marxista de la pobreza y de los pobres. El cristianismo "no admite que s6́lo el proletariado sea el sujeto principal de la liberación y. mucho menos, el destinatario principal de la misma"16. Insiste, más bien, en que también el simplemente pobre posee un potencial salvífico y en la proclamación 
constante de que los pobres, por serlo, son los amados por Dios privilegiadamente.

\subsubsection{La liberación integral}

Digamos por último que Ellacuría propició e impulsó, junto con otros, la liberación, pero insistió -y no por pura rutina- en que ésta debe ser integral, lo cual se desprende no sólo de la fidelidad normal al magisterio de la Iglesia que as 1 habla de la liberación-, sino de lo cristiano.

En el artículo ya citado sobre liberación, afirma que "la liberación del pecado, de la muerte y de la ley es parte esencial de la propuesta liberación integral, tal como ésta ha de verse desde la fe cristiana"17. Y desde otro punto de vista aborda la integralidad de la liberación con estas palabras:

La liberación es, ante todo, liberación de las necesidades básicas sin cuya satisfacción asegurada no puede hablarse de vida humana, ni menos aún de vida digna tal como corresponde a los hijos de Dios a quienes el creador regaló un mundo material común y comunicable... La liberación es, en segundo lugar, liberación de los fantasmas y realidades que atemorizan y atemorizan al hombre... es lo que debiera llamarse libertad de represión... Supuestas estas dos liberaciones, pero en simultaneidad con ellas, está la liberación tanto personal como colectiva de todo lipo de dependencias... (que) quitan la libertad cuando están interiorizadas... Está finalmente la liberación de sí mismo, pero de sf́ mismo como realidad absolutamente absoluta, que no lo es, y que posibilita la idolatría18.

La insistencia en la liberación y la esperanza de salvación, en lo que tienen de indeclinable, totalizante y de estar enraizadas en el abajo de la historia le vino dado a Ellacuría, en definitiva, por la tradición cristiana: la realidad es también mysterium salutis, o, dicho latinoamericanamente, mysterium liberationis.

\subsection{El potencial de lo cristiano}

Este modo de enfocar y abordar importantes realidades históricas, la ultimidad del pecado y la necesidad de cargar con él, la esperanza de salvación, los bienes de la pobreza, la desconfianza radical hacia el poder, etc., expresa cómo lo cristiano configuraba su persona. Para intentar argumentar racionalmente en favor de ello pudieran buscarse elementos en filosofias e ideologras - cosa que también hacía Ellacurfa-, pero, en mi opinión, fue el cristianismo y, en definitiva, sólo la tradición cristiana la que sustentaba su radicalidad y coherencia.

En cualquier caso fueron testigos cristianos, como Juan XXIII, Monseñor Romero19 y el Padre Amupe20 - a quienes querfa y veneraba- quienes le movlan a pensar de esa forma y a actuar consecuentemente. Nacio y crecio en esa 
tradición, con ella tuvo que habérselas ante sospechas y críticas, teóricas y prácticas, pero, por decirlo con sencillez, en nuestra opinión, nada como lo cristiano le ayudó a comprenderse a sí mismo y a comprender la historia, a hacerse él mismo persona y a hacer de la historia una historia humana.

Para Ellacurfa, la fe cristiana no anula la validez de filosoffas e ideologías, pero en momentos claves de la vida y ante realidades importantes la fe cristiana parecía lungir para él como una especie de reserva de verdad a donde no llegan -ni pretenden llegar- muchas de aquéllas, y de la que él sacaba lucidez y arrestos. Por una parte, insistía en que ni la fe, ni siquiera la Iglesia, es decir, lo cristiano, está capacitado por sl sólo para hacer real la totalidad de la liberación, pero por otra, estuvo convencido de que su aporte es imprescindible:

Carece de sentido objetar que la enseñanza social de la Iglesia o la teología de la liberación no ofrecen soluciones plenamente operativas a los problemas de la humanidad. De esa carencia no se sigue que su aporte histórico sea inútil o pueda ser sustituido por el de otros. La liberación integral no se puede lograr sólo con los instrumentos que ofrece la fe, pero no puede lograrse sin ellos. La integridad de la liberación exige esa presencia de la fe21.

Esta convicción de Ellacuría es, en mi opinión, una forma importante en que se expresa su fe. Y digamos para terminar este apartado, que precisamente en el hacer fructfero del potencial de la tradición cristiana vio Ellacuría la misión fundamental de la Iglesia, a lo cual llamó, bellamente, su maternalidad:

El carácter maternal de la Iglesia dice lo que ella tiene de partera de humanidad y de santidad, de partera de nuevos impulsos e ideas en favor de la liberación, y este carácler le corresponde a quien Dios se lo ha dado por el Espíritu de Cristo... Configurada la Iglesia como pueblo de Dios más por las fuerzas matemales que por las magisteriales dentro de ella, estará en mejor posición para dar su contribución a la liberación de los hombres y de la historia22.

\section{Ante el misterio de Dios}

Lo cristiano que configuró las realidades más importantes de la vida de Ellacuŕa estuvo también transido de transcendencia. Esto, a mi entender, lo analizó en mayor detalle en su discurso filosoffico que en el teológico, pero en cualquier caso, hay que recalcar que Ellacuría no ignoro ni la historia ni la transcendencia, lampoco las separó ni las mezcló en honda fidelidad a Calcedonia, sino que reformuló la relación entre ambas como transcendencia en la historia, de modo que de esta forma la historia va dando más de sl.

\subsection{Le historia grávida del "mís"}

En mi opinion, Ellacurfa fue un convencido de la transcendencia, y cierta- 
mente en su manifestación histórica. En su visión teórica y en la dirección de su praxis, siempre fue fiel a ese "más" que encontró en la historia, y personalmente trató de responder y corresponder a una historia siempre grávida del "más". En ello estuvo influyendo el principio zubiriano "que la realidad dé más de sî", pero sobre todo el "magis" ignaciano, según aquello de que no basta hacer bien las cosas, sino que hay que hacerlas "a la mayor gloria de Dios". Lo fundamental, sin embargo, es la honda convicción de Ellacuría de que no se puede comprender la realidad sin aceptar, de alguna forma, la transcendencia.

Si esto es así, queda la última pregunta, la más honda. Ya dijimos que la persona de Ellacuría quedó impactada y configurada por la aceptación del mysterium iniquitatis y del mysterium salutis que permean la historia. Queda por ver cómo tras ello está la fe en el misterio de Dios, el Deus semper maior, dicho en lenguaje de transcendencia; el Dios de Jesús, dicho en lenguaje bíblico - formulaciones ambas que él solra usar con frecuencia.

Formular cómo fue su fe personal no es nada fácil. Ciertamente, Dios y Cristo aparecen tratados con frecuencia y en profundidad en sus escritos. Es sabido también que conocía y apreciaba grandemente el pensamiento zubiriano sobre Dios23, y escribió un magistral arlículo filosófico sobre la fe24. En su pensamiento teológico, la salvación histórica es la actualización de la transcendente, "como una mayor presencia del Dios siempre mayor"25. En homillas y discursos hablaba de Dios con naturalidad, y en lo que de él dependía, propiciaba el trabajo pastoral sobre todo entre la gente pobre y sencilla, por su convicción de que la fe en Dios les da lucidez, fortaleza, ánimo y dignidad26. Celebraba y participaba en la eucarisúa con devoción, y presidió la misa que celebramos en la UCA a los pocos días del asesinato de Monseñor Romero. En ella, visiblemente emocionado, dijo estas conocidas palabras: "con Monseñor Romero Dios pasó por El Salvador". Estas palabras, que tantas veces he citado como homenaje de Ellacurfa a Monseñor Romero, las traigo ahora a colación como expresión de la fe de Ellacuría. En efecto, nada dado a usar en vano el nombre de Dios, y nada dado a usar en vano el nombre de Monseñor Romero, dijo - y confesó - que en Monseñor se le hizo presente esa realidad misteriosa que nosotros llamamos Dios.

Pero, dicho todo esto, es también verdad que no se puede fácilmente poner en palabra la fe de Ellacuría - ni la de ninguna otra persona-, lo cual se agrava en su caso, pues era alejado por carácter de manifestaciones intimistas y de palabreŕa sensiblera. Por ello, lo que voy a decir a continuación es, más bien, mi percepción de su fe $-\mathrm{y}$ honrada convicción-, basada más en la intuición que proviene del contacto personal prolongado que en la reflexión sobre los textos que nos ha dejado Ellacurra. Y quisiera añadir que está también basada en lo que yo personalmente creo haber recibido de Ellacurfa en forma de fe.

Cambiamos, pues, de método y, sin basarme ni citar mucho de sus escritos, 
intentaré decir lo que en mi opinión era el misterio de Dios para Ellacuría. Y lo voy a hacer en reflexiones basadas en recuerdos personales.

\subsection{La fascinación de Jesús, sacramento del misterio de Dios}

Mi primera reflexión es sobre Jesús de Nazaret. Por el modo como hablaba de él, no sólo cuando argumentaba teológicamente con el Jesús histórico para convencer a un adversario de por dónde debían ir las cosas en la Iglesia y en la Compañía de Jesús, es claro para mí que Jesús ejerció una poderosa atracción sobre Ellacuría, y me parece que ésta consistía en lo siguiente. En primer lugar, la misión de Jesús, el anuncio y la construcción del reino de Dios para los pobres, la defensa de los débiles, marginados y víctimas, y la denuncia de los opresores, poderosos de todo tipo. Y en segundo lugar, el modo de ser de Jesús, sus actitudes ante la vida y la muerte, su honradez con la verdad, su misericordia, su firmeza hasta el final, su activa disponiblidad ante Dios.

Lo importante, sin embargo, no está en los detalles, sino en el impacto global. Ese Jesús, el de Nazaret, que no fue filossolo como Zubiri, ni teólogo como Rahner, ni economista como Marx, creo que le fascinaba profundamente. No lo expresaba con palabras melifluas, pero un día se emocionó hablando de él, y así lo cuenta uno de sus oyentes:

En un curso abierto de teología el P. Ellacuría estaba analizando la vida de Jesús y de pronto se le fue la racionalidad y se le desbordó el corazón. Y dijo: "Es que Jesús tuvo la justicia para ir hasta el fondo y al mismo tiempo tuvo los ojos y entrañas de misericordia para comprender a los seres humanos". Ellacu se quedó callado y concluyó hablando de Jesús con estas palabras: "fue un gran hombre"27.

Personalmente estoy convencido de que Jesús de Nazaret causó gran impacto en Ellacuría y que ejerció una fascinación difícil de poner en palabra. Mi impresión es que al hablar de Jesús aparecla un Ellacuría distinto y que el hablar sobre Jesús lo hacía sentirse y expresarse de manera distinta a la habitual. Eso se echaba de ver cuando hablaba de Jesús a propósito de los ejercicios de san Ignacio o a propósito de la teología de la liberación. Y recuerdo su emoción sosegada- cuando, siguiendo a su admirado maestro Rahner, hablaba de Jesús como sacramento de Dios. En mi opinión, Ellacuría quería comunicar algo semejante a lo que dice la carta a Tito: en esta historia nuestra ha aparecido en un ser humano lo sumamente bueno, la benignidad y humanidad de Dios salvador nuestro.

\subsection{Ante Dios en la fe de Monseñor Romero}

La segunda reflexión - y la definitiva para la fe de las personas-es sobre el misterio de Dios. A ml se me ocurre pensar con frecuencia cormo es la fe de las personas, y especialmente la de aquéllas que han sido importantes para mi 
propia fe, el Padre Amupe, Monseñor Romero y otros. Por ello me he preguntado también cómo era la fe de Ellacuría, qué problemas tenía y cómo los abordaba, qué era para él el misterio de Dios y sobre todo qué mantenía su fe en ese misterio, a la vez tan luminoso y tan oscuro. Y pensando en ello siempre se me han ocurrido dos cosas. Una es que la fe de Ellacuría tuvo que pasar por algún tipo de oscuridad, y la otra es que por honradez con la realidad y por fidelidad primigenia - a la realidad, a la tradición, a la fe, en definitiva, a sí mismo-. vivió y se mantuvo remitido a un misterio, que era el misterio de Dios.

Ese misterio -que en cuanto misterio es "aquello a lo que sólo se le puede dejar ser"- creo que fue una realidad en su vida. Quizás pueda describirse la relación con el misterio de esta forma: hay que dejar a Dios ser Dios y es bueno para los seres humanos dejarle ser Dios. Quizás pueda expresarse en la esperanza con que termina su último artículo teológico: "más allá de los sucesivos futuros históricos se avizora el Dios salvador, el Dios liberador". En cualquier caso, Ellacuría tuvo que habérselas con Dios y se las hubo con Dios.

Eso es lo que traté de poner en palabra -que no explicar- en la carta que le escribí un año después de su asesinato y que reproduzco al final de este escrito. Y sobre esto quiero hacer ahora una breve reflexión, intuición más bien, pero que, al menos para mí, tienen gran significado por haber vivido muchos años con Ellacuŕa y por haber llegado a formulármela después de preguntarme muchas veces cómo era su fe, qué era en definitiva lo que le hacía vivir y qué es lo que le condujo a entregar su vida y aceptar la muerte con naturalidad.

La reflexión versa sobre el impacto que Monseñor Romero causó en la fe de Ellacuría. En el discurso que pronunció cuando la UCA le olorgó póstumamente un doctorado honoris causa, Ellacuría dijo lo siguiente:

Se ha dicho malintencionadamente que Monseñor Romero fue manipulado por nuestra universidad. Es hora de decir pública y solemnemente que no fue así. Ciertamente, Monseñor Romero pidió nuestra colaboración en múltiples ocasiones y esto representa y representará para nosotros un gran honor, por quien nos la pidió y por la causa para la que nos la pidió... Pero en todas esas colaboraciones no hay duda de quién era el maestro y de quién era el auxiliar, de quién era el pastor que marca las directrices y de quién era el ejecutor, de quién era el profeta que desentrañaba el misterio y de quién era el seguidor, de quién era el animador y de quién era el animado, de quién era la voz y de quién era el eco28.

Referirse a alguien, como aquí lo hace Ellacurfa al hablar de Monseñor "Monseñor Romero ya se nos había adelantado", solía decir-, fue algo realmente inusitado en él, y algo que, por otra parte, fue dicho con total sinceridad y no como concesión al estilo laudatorio en la entrega de un doctorado. Y también sorprende por lo inusitado esta otra constatación. Ellacuría fue de carácter 
conocidamente crítico, y por ello rara fue la persona - aun cuando, por otra parte, la quisiese y admirase con sinceridad - que no fuese alguna vez objeto de su crítica. Pues bien, que yo recuerde sólo de Monseñor Romero nunca le oí criticar. Lo admiró extaordinariamente y lo alabó con total sinceridad29.

Todo esto significa para mí que Ellacuría vio en Monseñor $-\mathrm{y}$ en la totalidad de Monseñor- algo sumamente especial que le fascinó, y que la alabanza y el agradecimiento expresados en su discurso reflejaban no sólo el impacto beneficioso de Monseñor Romero para la UCA, sino también para él y en lo más hondo de su persona. Vivir en el ámbilo de realidad de Monseñor Romero, con su compromiso con los pobres y con su fe en Dios, por decirlo con palabras sencillas, eso es vivir en verdad — parecía decir Ellacuría. Y ello no como tesis genérica, sino como realidad existencial para él.

Para $\mathrm{ml}$ no hay duda de que Ellacuría quedó real y existencialmente impactado por Monseñor Romero y de forma diferente a como le pudo impactar un Rahner o un Zubiri. La profecía y la misericordia, la utopía y la libertad de Monseñor dejaron clara huella en él. Pero en mi opinión lo más hondo y específico fue otra cosa: la honda fe de Monseñor Romero, su fe en el misterio de Dios al que Monseñor se dirigía con naturalidad no fingida y que asomaba en su persona 30.

Como ya he dicho antes, después del asesinato de Monseñor Romero, Ellacuría dijo: "con Monseñor Romero Dios pasó por EI Salvador". Estas palabras no le salieron en absoluto en forma estudiada para decir algo memorable que le pudiera dar notoriedad, sino que le salieron como palabras de inmenso cariño, admiración y agradecimiento, pero fueron sobre todo palabras espontáneas, salidas de lo más hondo de su ser, en las cuales - quizás, sin pretenderlo- el mismo Ellacuría dijo algo hondo e importante sobre él mismo, y fueron palabras que, por ello, nos introducen en el misterio de Ignacio Ellacurfa: en esta historia nuestra, a pesar de todo, contra toda esperanza, muchas veces se puede ver el paso de Dios.

Para Ellacuría personas como Monseñor venían a ser como el rostro de Dios en nuestro mundo, rostro en definitiva más fascinans que tremens. $\mathrm{Y}$ no sólo eso, en presencia de Monseñor Romero se sentía brado a eso- empequeñecido, pero con un empequeñecimento que no humilla, sino que engrandece y otorga dignidad. Se sentra llevado en su fe por la fe de Monseñor. El Ellacuría a quien en casi todas las otras cosas le tocaba ir por delante y llevar a otros, en la fe se sentía llevado por otros ${ }^{31}$, lo cual es uno de los elementos inherentes a la fe, unido dialécticamente al de la soledad y la responsabilidad indelegable.

En conclusión, yo dirfa que Ellacuría vio en Monseñor Romero a un hombre de Dios y que vio a Dios en ese hombre. La verdad y la profecía, la misericordia 
y la justicia, la utopía y la gracia, y la diffcil simultaneidad de todo ello que afloraba sin limites en Monseñor, le hizo - indefensamente- presente a Dios. Yo creo que Ellacurla vio hecho realidad en Monseñor el deseo que todos llevamos dentro: que Dios es bueno y que es bueno que haya Dios. Y eso que vio en Monseñor Romero de forma personal y excepcional, lo vio también en algunas gentes sencillas que él conocía: en la pobreza, en la sencillez, en la esperanza y en la dignidad de esta gente veía él la huella misteriosa de Dios. En los pueblos crucificados, sobre todo, veía el sacramento de la presencia de ese misterioso Dios en el mundo. Ese "avizorarse el Dios salvador" es una forma de expresar le-esperanza en el misterio de Dios. Si buscamos, para terminar este apartado, algunas citas que muestren al Monseñor Romero en el que Ellacuría se reconocía, que puedan expresar el influjo de Monseñor en su propia fe, quizás puedan servir éstas:

Sobre dos pilares apoyaba (Monseñor Romero) su esperanza: un pilar histórico que era su conocimiento del pueblo al que él atribuía una capacidad inagotable de encontrar salidas a las dificultades más graves, y un pilar transcendente que era su persuasión de que últimamente Dios es un Dios de vida y no de muerte, que lo último de la realidad es el bien y no el mal. Esa esperanza no sólo le hacía superar cualquier tentación de desaliento, sino que le animaba a seguir trabajando, consciente de que su esfuerzo no iba a ser baldío por más que fuera corto el tiempo32.

Monseñor Romero nunca se cansó de repetir que los procesos políticos, por muy puros e idealistas que sean, no bastan para traer a los hombres la liberación integral. Entendía perfectamente aquel dicho de san Agustín que para ser hombre hay que ser "más" que hombre. Para él, la historia que sólo fuese humana, que sólo pretendiera ser humana, pronto dejarla de serlo. $\mathrm{Ni}$ el hombre ni la historia se bastan a sí mismos. Por eso no dejaba de llamar a la transcendencia. En casi todas sus homilías salía este tema: la palabra de Dios, la acción de Dios rompiendo los limites de lo humano33.

\subsection{El humilde caminar con Dios}

La tercera reflexión es que la fe de Ellacuría no pudo ser ingenua, obviamente. Desde la perspectiva de la razón muchas son hoy las dificultades para aceptar a Dios. Los filósofos contemporáneos, con pocas excepciones como la de Zubiri, hacen profesión de agnosticismo o ateísmo. Ellacuría, además, se formó intelectualmente en una época en que se hablaba mucho de secularización y aun de muerte de Dios.

Mayor todavia me parece a mí la dificultad que proviene del escándalo del tercer mundo. Por ello no creo yo que pueda ser posible la fe en Dios - ni para Ellacuría ni para cualquier otra persona mínimamente reflexiva - sin que ante la tragedia de ese mundo surja de alguna forma la pregunta de la teodicea: el por 
qué del mal en este mundo si existe un Dios bueno y poderoso. $Y$ eso se agrava todavía más en América Latina, donde la fe y la teología lo confiesan como un Dios de vida, un Dios en favor de las víctimas. Como muesira de ello, sólo voy a reproducir un testimonio, el de un sacerdote que después de la masacre de El Mozote, en 1981, se hace las siguientes reflexiones y preguntas:

Más de mil campesinos asesinados. No exagero. Yo vi muchos de los cadáveres mutilados, deshaciéndose. Días después se sentía aún un olor insoportable. Las casas destruidas, todos muertos... En aquel pueblito que para mí era la alegría, eran mujeres y niños, esos niños que nunca vemos en la montaña jugando... El Mozote, un caserlo tan alegre, con tanta vida... Cuando miré las pilas de los muertos, la destrucción, no pude aguantar. ¿Cómo es posible que precisamente aqui, a donde he llegado tantas veces para decir que Dios es un Dios cercano y que nos quiere, que no queda indiferente ante el dolor, que precisamente aquí suceda una masacre tan espantosa?34.

$Y$ no sólo el sacerdote europeo, estudiado y que ha pasado por la ilustración, sino también los campesinos se hacen la misma pregunta:

Cuántas veces no decimos que Dios actúa en nuestra historia... Pero, Padre, y si actúa, ¿cuándo acaba esto? ¿Y tantos años de guerra y tantos miles de muertos? ¿Qué pasa con Dios? ?s.

Cómo se hace cada uno esa pregunta, cómo hace cada uno ese cuestionamiento a Dios y cómo se responde cada uno ante todo ello es algo sumamente personal. Sólo quiero recordar, primero, que esta no es ninguna novedad, y, segundo, que a lo largo de la historia - y en la misma historia de la revelación- aparecen con claridad y sin disimulos esas preguntas y cuestionamientos, y en diversas formas: la protesta de Jeremlas ante un Dios silente y que lo deja indefenso, la pregunta doliente de Job, al que s6lo le queda aceptar que es creatura y no Dios, el escepticismo del Qohelet, el silencio de Dios en la cruz de Jesús... Pues bien, no por curiosidad, sino por honradez, me he preguntado muchas veces qué figura de entre las mencionadas expresarfa mejor la experiencia de los creyentes latinoamericanos, quienes, a pesar de todo, siguen caminando. trabajando y viviendo sus vidas con sentido y con fe.

A mí parecer es inevitable que personas como Ignacio Ellacuría reproduzcan en momentos de su vida algunas de las experiencias mencionadas o algunos aspectos de ellas, pero en ellos aparece también otro tipo de experiencia $-y$ al parecer, la más fundamental- de la que también habla la revelación. Es la del pasaje tantas vectes citado de Miqueas: "Ya se te ha declarado, oh hombre, lo que es bueno y lo que el Señor desea de ti: practicar la justicia, amar con ternura y caminar humildernente con Dios" $(6,8)$. Según este texto y en un momento solemne de la revelacion, sea cuales fueren las preguntas y cuestionamientos de los seres humanos a Dios, es Dios mismo quien dirige a los seres humanos una 
palabra que exige e invila a caminar, caminar en el que la vida y la fe pueden encontrar último sentido.

En mi opinión, este texto pudiera reflejar bien la vida de personas como Ellacuría. En él se dice que, aun cuando el ser humano puede preguntar a Dios, él es también preguntado, y a esa pregunta tiene que responder. La respuesta puede ser dicha en palabra, pero en definitiva - si es que el ser humano da una respuesta - tiene que ser puesta por obra, y desde ella es también donde nuestra pregunta por Dios puede tener una respuesta existencial. Lo que la revelación dice entonces es que hay una dialéctica entre preguntar y ser preguntado. Pues bien, en mi opinión, Ellacuría - sea cuales fueren sus preguntas- nunca dejo de comprenderse a sí mismo también como el preguntado, y toda su vida —práctica de la justicia en fidelidad hasta el final- puede ser interpretada como la respuesta práxica a la pregunta que dirige Dios. Eso lo tenemos que hacer los humanos en humildad - por la oscuridad inherente al misterio-, pero también en lucidez, pues el misterio vivido en justicia y temura no es sólo oscuridad, sino también exceso de luminosidad.

Es claro que Ellacurfa nunca dejo de caminar en la historia con misericordia y lidelidad, como dice de Jesús la Carta a los Hebreos, y de ahí que podamos interpretar su vida también como una vida de confianza en la bondad última, un Dios que es Padre, y de activa disponibilidad a la exigencia última, un Padre que sigue siendo Dios. En otras palabras, hay que dejar a Dios ser Dios y es bueno dejarle que sea Dios. Ese caminar suyo en la historia más se parece al de Miqueas que al cantado por Machado, y es un caminar hacia Dios ${ }^{36}$. Efectivamente "el caminante no hay camino, se hace camino al andar", hondo, existencial, siempre cuestionante y también posiblemente animante, en medio de la práctica de la liberación puede ser reformulado en la línea de Miqueas, como lo ha hecho don Pedro Casaldáliga:

Camino que uno es que uno hace al andar.

Para que otros caminantes puedan el camino hallar.
Para que los atascados se puedan reanimar. Para que los ya perdidos nos puedan reencontrar 37 .

En otras palabras, es éste un caminar des-centrado: "haz del canto de tu Pueblo el ritmo de tu marchar"38. Y ese caminar des-centrado, el exigido por Miqueas, permite que pueda ser comprendido y crefdo en fe como un caminar con Dios.

\section{El mayor amor}

La misericordia hacia los pobres y la fidelidad al humilde caminar llev6 a Ignacio Ellacuria a la muerte 39. De el se puede decir con verdad que le quitaron la vida, pero sobre todo que la entregó libremente. Se la quitaron porque estorb6, pero la dio porque amb. 
Queremos, para terminar, decir una palabra sobre su martirio en el contexto más amplio del martirio de sus compañeros jesuitas de la UCA y de lodos los mártires salvadoreños. Aquí, sobre todo, me basaré en recuerdos personales, más que en sus textos sobre el martirio.

\subsection{Por qué recordar el martirio}

Volver sobre el martirio no es rutina ni masoquismo, sino que es bueno y necesario. Lo es por agradecimiento, y el no hacerlo deshumaniza. Lo es por dar consuelo a los supervivientes, a los familiares sobre todo. $\mathrm{Y}$ lo es porque el martirio da luz sobre dos cosas importantes.

La primera es sobre el objeto de este ensayo: conocer a Ellacuría, su persona y su fe. Si es cierto que el fin da sentido al proceso, como decía Hegel, si al final hay que pasar un examen, como decla san Juan de la Cruz, y si también al final seremos juzgados con ultimidad, como dice Jesús en el relato del juicio final, es bueno saber cómo fue el final de Ellacuría para mejor conocerlo y para mejor "evaluar" su figura. Así, sabremos también si su destino confimna su visión histórica y cristiana de las cosas - y sabremos qué uipo de tradición puede generar ese martirio.

Preguntarse esto es posible y tiene sentido porque la muerte martirial es una realidad dual. Es a la vez asesinato-martirio, en palabras que el mismo Ellacuría solía usar para analizar la muerte de Monseñor Romero. En cuanto asesinato, esa muerte es oscuridad, mysterium iniquitatis. Pero en cuanto martirio, es también luminosidad, mysterium saluris. $\mathbf{Y}$ tener presentes ambas cosas es muy importante - sobre todo cuando se nos las quiere hacer olvidar.

Pero, además, el martirio de Ellacurfa y de los otros mártires también da luz sobre lo central de la fe cristiana. Desde esos martirios, en efecto, se comprende mejor el final de Jesús, su cruz y resurrección, y por ello también desde ellos se comprende mejor el origen de la fe y de la Iglesia, cuyo nacimiento hay que verlo, con la tradición, en la cruz de Jesús - más la efusión del Espíritu. En otras palabras, Jesús muere en la cruz con un gran grito - la oscuridad del asesinato-, pero ese grito es recogido por Dios en la resurrección, y es recogido también por hombres y mujeres en su seguimiento. De esa forma, la cruz genera fe y funda historia - la luminosidad del martirio.

Pues bien, Ellacurfa y muchos otros mártires latinoamericanos han muerto -objetivamente- de forma semejante a como murió Jesús, y eso ha ocurrido porque vivieron de forma semejante a como vivió Jesús. Si se me permite una brevísima digresión para captar el significado de lo que acabamos de decir, es sabido que hace un siglo se descubrio la intención original de la mision de Jesús: el reino de Dios, no en directo la Iglesia. Pues bien, este descubrimiento ha hecho comprender mejor no sólo la persona y causa de Jesús, ni sólo a la 
Iglesia como servidora y sacramento del reino, sino también lo que es el seguimiento de Jesús y el martirio cristiano, visto ahora todo ello desde el reino de Dios.

En nuestra opinión, no hay duda de que muchos cristianos han vivido en América Latina como Jesús, anunciando e iniciando el reino de Dios, optando, apoyando y defendiendo al pobre y al débil, denunciando y desenmascarando al poderoso y al opresor. Por ello han sido difamados, perseguidos y asesinados como Jesús. Y por ello también muchos se han puesto ante Dios, pidiendo que pase el cáliz, pero haciendo su voluntad hasta el final. En definitiva, han mostrado un gran amor, y eso hace también que -análogamente a la resurreción de Jesús - su presencia siga viva históricamente en el hospitalito de la Divina Providencia, en el jardín de rosas, en El Despertar y en muchos otros lugares de El Salvador. Recordar, pues, a los mártires de hoy es una gran ayuda para comprender a Jesús y para comprender la fe y la Iglesia que surgieron de su cruz y resurrección 40 . Y esto da la medida del grave mal que el olvido de los mártires actuales origina dentro de la Iglesia.

A continuación vamos a reflexionar sobre el martirio de Ellacuría en el transfondo salvadoreño y en el transfondo de lo que le sucedió a Jesús. Con ello conoceremos mejor quién fue él, pero también cuál es la realidad de nuestro país y de nuestra fe.

\subsection{Una muerte asimida}

Ellacuría fue muy consciente de la posiblidad de que lo mataran, aunque no solía hablar mucho de ello por dos razones, creo yo. La primera, como ya hemos dicho, es que no era muy dado a hablar de cosas personales y, menos aún, íntimas. La segunda es que, como responsable de una institución grande y amenazada, y como líder natural que era, no quería en modo alguno cooperar al miedo ni menos generar pánico. Por ello, cuando alguien trafa rumores de peligros inminentes, comentaba que ya estábamos con "el apriori catastrófico".

Sin embargo, en aquellos dias se hablaba de estas cosas por necesidad. El P. César Jerez, provincial de los jesuitas de 1976 a 1982, decía: "si me secuestran, no pagen un centavo". Y otro decía: "la muerte es tolerable, pero que no me torturen". Estas conversaciones mostraban en defínitiva cómo todos, cada uno a su modo, pensaban en la posiblidad de la muerte. Como he dicho, Ellacurfa no era dado a hablar de esas cosas, pero a veces comentaba, como para quitar importancia a la muerte, que "el dolor podía durar sólo veinte segundos". Y recuerdo que en otra ocasión, recordábamos lo que decla Epicuro ante el miedo que origina el pensamiento de la muerte, que más o menos dice asf: "si estoy vivo no tengo por qué preocuparme, y si estoy muerto ya no puedo preocuparme". 
Traigo a colación estos recuerdos simplemente para recalcar lo obvio: Ellacuría fue muy consciente del peligro que corría, aunque subjetivamente lo sabía manejar, y, por otra parte, no quería comunicar pánico. Pero en cualquier caso no eslá de más recordar la persecución de que fue objeto, pues ello muestra no sólo que no fue ingenuo en absoluto, sino que asumió la muerte con libertad y por amor.

Contra Ellacuría se expresaron con frecuencia y muy virulentamente oligarcas, militares y también gobernantes 4 . Los insultos y calumnias en los diarios se convertieron en cosa proverbial42. Desde enero de 1976 hasta noviembre de 1989, en quince ocasiones, explotaron bombas en la UCA y en lugares críticos como el edificio de administración central, el centro de cómputo, la biblioteca, la oficina de $E C A$ y, sobre todo, la imprenta. En cuatro ocasiones los cuerpos de seguridad catearon nuestra residencia privada y en otras cuatro nos pusieron bombas.

Si estos ataques iban dirigidos contra todos, a él lo persiguieron y amenzaron muy especialmente. Desde comienzos de los años setenta recibió amenazas personales de muerte y muchas veces encabezaba las listas de los que iban a ser asesinados. En 1977 no pudo regresar a El Salvador tras el asesinato de Rutilio Grande - y dijo en Madrid, donde estaba, que no pudo dormir en toda la noche al enterarse del asesinato.

Para explicar de forma gráfica la persecución a Ellacurfa - y la barbarie en el pals- bastará recordar lo ocurrido en 1980. Ese año asesinaron a Monseñor Romero, a otros cuatro sacerdotes, Cosme Spezzotto, Manuel A. Reyes, Ernesto Abrego y Macial Serrano, a cuatro misioneras norteamericanas, Ita, Maura, Dorothy y Jean, a un seminarista a punto de ordenarse, Otmaro Cáceres, por mencionar a personas religiosas. Pero también ese año asesinaron a Félix Ulloa, rector de la Universidad Nacional, a los cinco máximos dirigentes del Frente Democrático, con su presidente Enrique Alvarez Córdoba, y a los centenares de campesinos masacrados en el Sumpul... Pues bien, al final de ese año, Ellacurfa encabezaba una lista, confeccionada por militares, de personas que iban a ser asesinadas. Tuvo que salir del país, a escondidas.

La conclusión de este breve recordatorio es que Ellacuría sabla que era posible y aun probable que fuese asesinado. $\mathrm{Si}$, a pesar de ello, siguió trabajando en el pás hasta el final, sin desviarse de su modo de ser, de hablar y de actuar, entonces su muerte muestra firmeza, libertad y amor.

Fue prudente, no suicida, como Jesús, quien al oír que hablan asesinado al Bautista, se retiró a otro lugar. Pero fue también firme y decidido, como Jesús. Este subió de Galilea a Jerusalén, donde iba a ser entregado. Ellacuria abandonó Espafia para regresar a El Salvador y decidió quedarse en la casa en plena ofensiva, a pesar de todas las advertencias en contra. Y siguiendo con el ejemplo de Jesús, recordemos que éste comenzó su misión "cuando fue apresado 
Juan", su amigo y maestro. A pesar de ello y quizás movido existencialmente por ello, Jesús prosiguió en ese momento - aunque de modo diferente- la misión de Juan y prosiguió ciertamente aquello por lo que Juan fue apresado: la denuncia profética. Algo semejante podemos decir de lo ocurrido en El Salvador: asesinado el profeta Rutilio Grande, surgí el profeta Monseñor Romero, y asesinado éste surgio - aunque ya había comenzado antes- el profeta Ignacio Ellacurґa.

Todo esto lo hizo con naturalidad. En los largos años de persecución, nunca vi que dudase de cuál era su misión y su lugar, ni que tuviese que discemir mucho sobre ello - lenguaje al menos, tan frecuente hoy en día entre religiosos. $Y$ es que "lo obvio no es objeto de discernimiento"43. Más aún, vio en el martirio algo bueno y necesario. Ya citábamos antes que "los cristianos deben estar dispuestos a ser los primeros y más arriesgados... hasta el martirio". Y entre las palabras de Monseñor Romero que más solía citar se cuentan las siguientes:

Me alegro, hermanos, de que nuestra Iglesia sea perseguida, precisamente por su opción preferencial por los pobres y por tratar de encarnarse en el interés de los pobres... Serfa triste que en una patria donde se está asesinando tan horrorosamente no contáramos entre las víctimas también a los sacerdotes. Son el testimonio de una Iglesia encarnada en los problemas del pueblo44.

Ellacuría estaba convencido, pues, de que la persecución y el martirio eran una necesidad histórica y cristiana, y los asumió con libertad. De esa forma pudo decir como Jesús "nadie me quita la vida, sino que yo la doy voluntariamente" (Jn 10, 18). Y en esa libertad está expresado el amor: "nadie tiene mayor amor que el que da su vida por los amigos" (Jn 15, 13).

\subsection{Cargar con el pecado}

¿Por qué mataron a Ellacuria? Aunque ya es sabido y se desprende claramente de todo lo dicho en estas páginas, no es ocioso volver a ello porque da luz sobre los mártires y sobre el país. Como en el caso de Jesús, se adujeron contra él dos tipos de razones. Las primeras eran razones concretas y simplemente falsas. Las segundas, más abarcadoras, no justificaban el asesinato, por supuesto, pero eran afirmaciones verdaderas. Veámoslo, comparándolo con las acusaciones a Jesús45.

Por lo que toca a lo primero, a Jesús en el juicio religioso se le acusó de blasfemia y en el juicio político de andar alborotando al pueblo. Nada de eso era cierto, pero ésas fueron las acusaciones. También a Ellacurfa lo acusaron de lo que en nuestro tiempo suena a "blasfemia": marxista, comunista, antipatriota, hasta ateo - y en el colmo de la ironía y de la tergiversación de la fe cristiana lo acusaron también de "liberacionista". Y también lo acusaron de alborotador: 
apoyar al FMLN y ser su fachada, fomentar la violencia, la guerra, el terrorismo...

No vamos a analizar ahora la falsedad de estas acusaciones, sino el fondo del asunto. Volviendo a Jesús, la condena se decide en el juicio religjoso en base a la acusación de que Jesús quiere destruir el templo, y en el juicio político en base a la oposición de Jesús al César. $Y$ ahí sí acertaron, pues, aunque Jesús no quería destruir físicamente el templo ni atentar físicamente contra el emperador, sí querla y proponía, y por eso trabajaba y luchaba, una sociedad muy distinta y aun contraria a la organizada alrededor del templo y según la pax romana. De igual modo, Ellacurla proponía una sociedad distinta y aun contraria a la actual, como hemos visto. Esa es la verdadera razón para asesinar a Ellacuría, a Monseñor Romero y a tantos otros.

Los asesinos, pues, dijeron cosas falsas y aberrantes contra Ellacuría, pero en lo fundamental no se equivocaron46. Monseñor Romero solía decir que "se mata a quien estorba", y Ellacuría estorbó grandemente a mantener una sociedad radicalmente injusta, opresiva y represiva, y luchó toda la vida por transformarla en una sociedad justa, con vida y libertad. No había, pues, razones para eliminarlo, pero sí había necesidad. Y esa necesidad no proviene de la crueldad de tal o cual persona, de tal o cual grupo, sino que es estructural: es la implacable reacción de los ídolos. En lenguaje de Monseñor Romero, “iAy del que toca el ídolo de la riqueza. Es como un cable de alta tensión. Se quema!".

Que existen fdolos en este mundo es conviccción profunda de la fe y de la teología en América Latina, y Ellacuría fue de quienes más contribuyó a su conceptualización teórica y a su desenmascaramiento profético. Resumiendo47, podemos decir que los Idolos son realidades historicas, realmente existentes, que se hacen pasar por divinidades, mostrándose con las caracterísicas de la divinidad: ultimidad, autojustificación, intocabilidad. Ofrecen salvación a sus adoradores - aunque lo que en verdad hacen es deshumanizarlos - y les exigen un culto y una ortodoxia. Y lo más especifico suyo es que - como el dios Moloch de la mitología- exigen víctimas humanas para subsistir.

Así teorizó Ellacuría la idolatria, pero además analizó y denunció cuáles son los ídolos concretos de El Salvador48. El primero, el más grave y el más originante de todos los demás es la absolutización del capital. El segundo es la seguridad nacional, la fuerza armada, los cuerpos de seguridad, los escuadrones, puestos al servicio de aquél. El tercero puede ser la organización popular y lo es en la medida en que se absolutiza y convierte en mistica a la violencia. Existen, pues, los Idolos, y el asunto es erradicarlos.

Ellacuria, en concreto, hizo esto sobre todo al analizar y denunciar la verdad de la realidad. Y eso que pareciera ser tan bueno y benéfico, es perseguido a muerte por los ídolos. $Y$ es que el ídolo - como el pecado- no sólo da muerte, 
sino que busca siempre su propio ocultamiento. Escándalo y encubrimiento son correlativos, y por ello decir la verdad es desenmascarar la mentira. Dicho todavía de otra forma, el mundo en que vivió Ellacuría $-y$ en el que vivimos los supervivientes- es a la vez un mundo de muerte y un mundo de mentira. Como dice el Nuevo Testamento, el maligno es a la vez asesino y mentiroso.

Ellacuría quiso liberar a la verdad de la esclavitud a la que la someten los opresores, poner luz en medio de la mentira, justicia en medio de la opresión, esperanza en medio del desconsuelo, amor en medio de la indiferencia, la represión y el odio. Por eso lo mataron. Y en ello cargó con el pecado del país.

\subsection{El jardín de rosas}

Queda la última pregunta. El Ellacuría que hablaba tan claramente de la necesidad de cargar con el pecado como el siervo de Yahvé, no sólo de combatirlo desde fuera, ¿ha traído también salvación histórica? La respuesta es importante, pero hay que aclarar desde el principio que esa salvación depende de nosolros, de si recogemos y ponemos a producir su herencia.

Ya es cosa reconocida que el martirio de Ellacuría y el de sus compañeros -por la magnitud y repercusión internacional del hecho, y por la coyunturaayudó sin duda a poner un fin negociado a la guerra. Pero además de esto hay que pensar en la salvación que Ellacuría y los mártires nos dejan a la larga. Esta salvación es real y consiste, según mi convicción, en haber generado una tradición histórica y real, sumamente necesaria y positiva. Significa que estos mártires, con su vida y con su muerte, han abierto un surco en la historia por el que es más fácil caminar, han dejado una fuerza que todavía actúa quasi ex opere operato por la potencia de esa fuerza y por la cercanía de los hechos. Indudablemente, esto supone también esfuerzo de los que les sobrevivimos, y somos nosotros los que podemos hacer más profundo el surco o poco a poco nivelarlo, facilitar o dificultar el caminar dentro de él.

Por lo que toca en concreto a Ellacuría, ojalá todo lo que hemos dicho en este escrito se convierta en tradición, pero quizás pudiéramos resaltar tres cosas en las que fue realmente ejemplar: el hambre y sed de justicia ante el pueblo crucificado, el analizar y denunciar incansablemente la verdad de su crucifixión, y la firmeza y fidelidad en su praxis hasta verlo descrucificado. Esta es la herencia y el refuerzo de una poderosa tradición que nos ha dejado.

¿Cómo marcha esa tradición en el país, en la Iglesia, en la UCA, en la Compañfa de Jesús? Todo ello habrá que analizarlo en detalle, pero para terminar mencionemos algo importante que ya es una realidad. Como ocurre con todas las tradiciones, los mártires ya se han convertido en símbolos, han dado nombre a comunidades, repoblaciones, centros de enseñanza, clínicas populares... Esta tradición ya tiene sus lugares sagrados: la capilla Monseñor Romero 
en la que están enterrados y el jardín de rosas. $Y$ tiene también sus poetas y cantores49. Por recordar sólo a uno de ellos, don Pedro Casaldáliga, esto es lo que escribió en marzo de 1990 ante el jardín de rosas:

Ya sois la verdad en cruz

y la ciencia en profecia

y es total la compañía

compañeros de Jesús.

El juramento cumplido,

la UCA y el pueblo herido

dictan la misma lección

desde las cátedras fosas

y Obdulio cuida las rosas

de nuestra liberación.

La misericordia hacia los pobres y la Tidelidad al humilde caminar llevó a Ignacio Ellacuría a la muerte. De él -y de muchísimos otros- se puede decir con verdad que le quitaron la vida, pero sobre todo que la entregó libremente. Se la quitaron porque estorbó, pero la dio porque amó. Todos los mártires son distintos, pero todos convergen en lo fundamental. Por ello quiero aplicar a Ignacio Ellacuría las palabras que é! mismo escribió sobre Monseñor Romero, poco después de su martirio:

Esa encarnación le gano el amor del pueblo oprimido y el odio del opresor.

Le ganó la persecución, la misma persecución que sufráa su pueblo. Así murió y por eso lo mataron. Por eso igualmente se convirtió en un ejemplo excepcional de cómo la fuerza del evangelio puede convertise en fuerza histórica de Iransformación. Por eso sigue viviendo tras su muerte... porque son muchos los que están dispuestos a seguir sus pasos, sabiendo que Monseñor Romero, en los últimos tres años de su vida pública, fue un seguidor ejemplar de Jesús de Nazaret50.

Con todas las diferencias que existen entre los seres humanos, lo mismo puede decirse de Ellacurla, de sus compañeros mártires de la UCA y de muchlsimos ouros.

Resumamos y terminemos. Ignacio Ellacuria fue un hombre y un cristiano excepcional y tuvo un excepcional influjo en el pars, en la Iglesia y en la Compañía de Jesús. Hemos tratado de mostrar cómo fue y por qué su influjo fue tan grande $y$ beneficioso. Como humano fue también limitado, tuvo fallos y limitaciones de carácter, y también cometió errores. Las páginas precedentes no están, pues, pensadas como panegírico, pero sigue siendo verdad que su persona fue excepcional y que es importante y benéfico proseguir su camino. 
Si me pidieran decir en breves palaras cómo recuerdo yo a Ignacio Ellacuría, el hombre y el cristiano, sólo puedo repetir lo que escrib́ en forma de carta en el primer aniversario de su muerte:

\section{Querido Ellacu:}

Desde hace años he pensado qué diría yo en la misa de tu martirio. Como en el caso de Monseñor Romero, nunca quise aceptar que eso llegara a ocurrir, pero tu muerte era bien verosímil, y la idea me ha dado vueltas a la cabeza muchas veces. Y éstas son las dos cosas que más me han impresionado de ti.

La primera es que tu inteligencia y tu creatividad me impactaron, evidentemente, y sin embargo siempre pensé que no era eso lo más específico tuyo. Para ti mismo fueron muy importantes, es cierto, pero no orientaste tu vida para convertirte en famoso intelectual ni prestigiado rector. Dicho con un ejemplo, recuerdo que en un exilio en España escribiste un manuscrito que te hubiera hecho famoso en el mundo de los filosofos, y sin embargo no le diste mayor importancia ni lo terminaste cuando viniste a El Salvador porque siempre tenías otras cosas más importantes que hacer: desde ayudar a resolver algún problema nacional hasta atender a los problemas personales de alguien que te pedía ayuda. La conclusion para mí es muy clara: más importante que el cultivo de tu inteligencia y el reconocimiento que esto te podria acarrear era para ti el servicio.

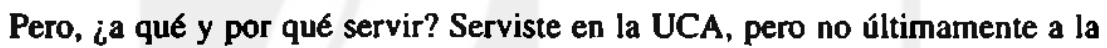
UCA. Serviste en la Iglesia, pero no últimamente a la Iglesia. Serviste en la Compañla de Jesús, pero no últimamente a la Compañía de Jesús. Cuanto más llegué a conocerte, más llegué a la convicción de que serviste a los pobres de este país y de todo el tercer mundo, y de que este servicio es lo que dio ultimidad a tu vida.

Eras discípulo fiel de Zubiri, filósofo y té́logo de la liberación, térico de movimientos políticos populares, pero no peleabas por esas teorías como si fuesen un "dogma". Más bien, cambiabas tus puntos de vista - tú, inflexible-, y cuando lo hacías, una sola cosa era lo que te hacia cambiar: la tragedia de los pobres. Por eso pienso que si algún "dogma" inamovible tuviste, éste fue sólo uno: el dolor de los pueblos crucificados.

Y eso me llevó a la conclusión de que ante todo y por encima de todo eras un hombre de compasión y de misericordia, de que lo último dentro de ti, tus entrañas y tu corazón, se removieron ante el inmenso dolor de este pueblo. Eso es lo que nunca te dej6 en paz. Eso es lo que puso a funcionar tu creatividad y tu servicio. Tu vida no fue, pues, sólo servicio, sino el servicio especifico de "bajar de la cruz a los pueblos crucificados", palabras muy tuyas, de ésas que no se inventan sólo con mucha inteligencia, sino con una inteligencia movida por la misericordia. 
Esta es la primera cosa que quería mencionar. La segunda cosa tuya que recuerdo - y ésta es más personal- es tu fe en Dios. Y me voy a explicar. Tu contacto con los filósofos modernos -increyentes la mayoría de ellos, con la excepción de tu querido Xavier Zubiri-, el ambiente de secularización y hasta de muerte de Dios que predominaba en la época en que alcanzaste lu madurez intelectual, tu propia inteligencia crítica y honrada, nada propicia a credulidades, y la gran pregunta por Dios que es en sf misma la injusta pobreza latinoamericana, nada de ello hace fácil la fe en Dios. Recuerdo un día, en 1969, en que me dijiste algo que no he olvidado: que tu gran maestro Karl Rahner llevaba con mucha elegancia sus propias dudas, con lo cual venías a decir que tampoco para ti la fe era algo obvio, sino una victoria.

Y, sin embargo, estoy convencido de que eras un gran creyente, y a mí, ciertamente, me comunicaste fe. Lo hiciste un día, en 1983, cuando al regreso de tu segundo exilio en España nos hablaste en una misa del "Padre Celestial", y yo pensé para mis adentros que si Ellacu, el cerebral, el crítico, el intelectualmente honrado, usaba esas palabras no era por puro sentimentalismo. Si hablabas del Padre Celestial era porque creías en él. Me comunicaste fe, muchas otras veces, al hablar y escribir sobre Monseñor Romero y su Dios, al hablar con sencillez de la religiosidad de los pobres. Y me la comunicaste con tu modo de hablar y de escribir sobre Jesús de Nazaret. En tus escritos expresas tu fe de que en Jesús se ha revelado lo que verdaderamente somos los seres humanos. Pero en ellos expresas también, agradecidamente, tu fe de que en Jesús se mostró ese "más" que nos rodea a todos, ese misterio último y esa utopía que todo lo atrae hacia sí. No sé cuánto luchaste con Dios, como Jacob, como Job y como Jesús, pero creo que Dios te vencí́ y que el Padre de Jesús orientó lo más profundo de tu vida.

Ellacu, esto es lo que nos has dejado, al menos a mí. Tus capacidades excepcionales pueden deslumbrar y tus limitaciones y defectos pueden ofuscar. Creo, Ellacu, que ni lo uno me ha deslumbrado ni lo otro ha oscurecido lo que para mf es lo fundamental que me has dejado: que nada hay más esencial que el ejercicio de la misericordia ante un pueblo crucificado y que nada hay más humano y humanizante que la fe.

Estas cosas son las que me han venido a la cabeza estos años. Hoy, a un año de tu martirio, las digo con dolor y con gozo, pero sobre todo con agradecimiento. Gracias, Ellacu, por tu misericordia y por tu fe.

Jon

\section{Notes:}

1. Esto puede apreciarse claramente en su artfculo "Teologfa de la liberación y marxismo", Revirta Latinaamericana de Teologla 20 (1990) pp. 109-135, sobre todo en la 
parte que titula "El aporte de la teología de la liberación al marxismo", pp. 127-135.

2. Ibid., p. 119.

3. "El pueblo crucificado. Ensayo de soteriología hisıórica", Revista Latinoamericano de Teología 18 (1989) p. 326.

4. "Palabras en el doctorado honoris causa en ciencias políticas al presidente de Costa Rica Dr. Oscar Arias", texto mimeografiado p. 6.

5. Que yo recuerde, Ellacurfa escribió dos importantes artículos sobre el tema de la violencia, uno al comienzo de los setenta y el otro a linales de los ochenta. "Violencia y cruz", en Teología política (San Salvador 1973), y "Trabajo no violento por la paz y violencia liberadora", Concilium 215 (1988) pp. 85-94.

6. "Apuntes para una espiritualidad en tiempos de violencia. Reflexiones desde la experiencia salvadoreña", Revista Latinoamericana de Teología 29 (1993) pp. 189208.

7. “Trabajo no violento...", p. 88.

8. lbid., p. 94.

9. Teología polírica (San Salvador 1973) p. 30.

10. "El papel de las organizaciones populares en la actual situación del pals", ECA 372373 (1979).

11. Teologia política, p. 8.

12. "Utopía y profetismo", p. 184.

13. "La mision...", p. 119.

14. Ibid., p. 119 s.

15. El texto de esta meditación es el siguiente. "Considerar el sermón que Cristo nuestro Señor hace a todos sus siervos y amigos, que a tal jomada envia, encomendándoles que a todos quieran ayudar en traerlos primero a suma pobreza espiritual, y si su divina majestad fuere servida y los quisiere elegir, no menos a la pobreza actual; segundo a deseo de oprobios y menosprecios, porque de esas dos cosas se sigue la humildad; de manera que sean tres escalones: el primero, pobreza contra riqueza; el segundo oprobio o menosprecio contra el honor mundano; el tercero humildad contra la soberbia y de estos tres escalones induzcan a todas las otras virtudes", Ejercicios espirituales n. 146. Sobre los Ejercicios espirituales, vistos desde América Latina, Ellacuría dio un curso en la UCA en 1974, cuyo texto publicamos póstumamente con el título "Lectura latinoamericana de los Ejercicios Espirituales de san Ignacio", Revista Latinoamericana de Teología 23 (1991) pp. 111-147, y, por lo que toca a la pobreza, pp. I28-133.

16. "Teologia de la liberación...", p. 134.

17. "Liberación...", p. 219.

18. Ibid., p. $224 s$.

19. Véase su escrito "Monseñor Romero, un enviado de Dios para salvar a su pueblo". Revista Latinoamericana de Teología 19 (1990) pp. 5-10, publicado originalmente en la revista Sal Terrae 1980.

20. Vease su escrito "Pedro Amupe, renovador de la vida religiosa", Revisia Latinoamericana de Teología 22 (1991) pp. 5-23.

21. "Liberación", p. 227.

22. Ibid., p. 228, 229s. Ellacuría esta jugando aquf con las palabras madre y maestra, con que se describe a la Iglesia. En el artículo explica ambas cosas, su mutua relación, su sujeto primario y, en definitiva, la prioridad de la maternalidad creadora sobre la magisterialidad reguladora. 
23. En 1984 edito y prologó como obra póstuma el libro de Zubiri El hombre y Dios (Madrid 1984).

24. "Voluntad de fundamentalidad y voluntad de verdad: conocimiento-fe y su configuracion histórica", Revista Latinoamericana de Teología 8 (1988) pp. 113131.

25. "Liberación", p. 226.

26. Por mencionar un solo ejemplo, cuando fue a Chalatenango con Monseñor Rivera a negociar con dirigentes del FMLN la liberación de la hija de Duarte, tuvo un especial interés en que Monseñor Rivera pudiese juntarse con los sacerdotes de la zona y, sobre todo, que pudiese animar religiosamenle a la gente.

27. Carta a las Iglesias 245 (1991) p. 10.

28. "La UCA ante el doctorado concedido a Monseñor Romero", ECA 437 (1985).

29. Para ser exactos, una vez expresó sus dudas - con respeto- sobre lo prudente de una decisión de Monseñor, y fue cuando, Iras la duda de si el P. Emesto Barrera había muerto luchando con un anma en la mano, Monseñor decidió presidir el funeral "seguro que estará su mamá", fue su argumento-, mientras a Ellacuría le pareció peligroso que lo hiciera por las tremendas críticas que caerfan sobre él de parte de las autoridades eclesiásticas.

30. Probablemente también le impactó de Monseñor Romero su cercanía directa, efectiva y afectiva, a las pobres - cosa que apreciaba también en Rutilio Grande-, quizás porque no era ésa su forma externa de vida.

31. Pienso también que se sentra llevado por la fe de la gente sencilla, sufrida, comprometida y esperanzada, con las que entraba en contacto en la vida cotidiana, y tal como la palpaba en los testimonios de Caria a las Iglesias, publicación a la que le tenía gran estima, precisamente por los testimonios de la gente.

32. "La UCA ante el doctorado...", p. 174.

33. "Monseñor Romero...", p. 9.

34. María López Vigil, Muerte y vida en Morazán. Testimonio de un sacerdote (San Salvador 1987) p. 94s. Ellacuría conocía bien este libro y al sacerdote que da el testimonio. Escribió un prólogo a la edición italiana del libro, que en español apareció publicado en Carta a las Iglesias, 168-170 (1988) pp. 7-10, 11-13, 5-7.

35. Ibid., p. 119.

36. También Zubiri nos ayuda a conceptualizar el acceso a Dios como un caminar real hacia Dios. "El acto o los actos de acceso del hombre a Dios no son los formalmente intelectivos, sino que son aquellos actos que fIsica y realmente nos llevan efectivamente a El en tanto realidad absolutamente absoluta ... Dios es constitutivamente accesible en las cosas reales mismas. Jamás, ni en el acceso supremo de los grandes místicos, se accede a Dios sin las cosas o fuera de ellas: se accede siempre a Dios en las cosas. Las cosas reales son la presencia personal de Dios", El hombre y Dios (Madrid 1984) pp. 181, 186.

37. "Cemino que uno es", en Cantares de la eniera libertad (Managua 1984) p. 47.

38. Ibid., p. 48.

39. Sobre el martirio de Ellacuría y sus companteros, véase lo que escribí a los pocos dias del asesinato: "Compañeros de Jesús. El asesinato-martirio de los jesuitas salvadoreños", ECA 493-494 (1989) pp. 1041-1074.

40. Dicho en términos técnicos, se da una circularidad hermentutica entre el mártir Jesús y los mártires actuales en Anérica Latina, a cause del horizonte del reino de 
Dios común a ambos, mientras que en otras épocas los mártires se han comprendido más desde Ia Iglesia que desde el reino de Dios. Esto no significa, obviamente, hacer ningún juicio sobre la santidad subjetiva de los mártires, de la Iglesia o del reino, ni relativiza, por supuesto, la preeminencia del mártir Jesús, pero sí ayuda a comprender en mutua referencia la cruz de Jesús y los martirios actuales.

41. También la institucion eclesiástica, algunas dependencias del Vaticano, el CELAM y algunos obispos del pals cuestionaron su ortodoxia y desaprobaban su actuación pública.

42. En una de sus más famosas apariciones en televisión junto a Rey Prendes y D'Aubuisson, a pesar de que rechazó con toda claridad que el marxismo y el comunismo fuesen el principio configurador de su persona, de su pensamiento y de su praxis, casi todas las llamadas durante el programa insistieron en acusarlo de marxista, entendido esto como el peor de los males.

43. Estaba tan convencido de que habla que corter riesgos que cuando mataron a Monseñor Romero, lo cual atribuían algunos a su denuncia la víspera, 23 de marzo, Ellacurfa insistra en que eso era lo que le tocaba hacer a Monseñor. Y también solía pedir a líderes políticos -después de algún tiempo de transcurrida la guerra- que regresasen al pais.

44. Citado en J. Sobrino, I. Martín-Baró y R. Cardenal, La voz de los sin voz La palabra viva de Monseñor Romero (San Salvador 1981) p. 454.

45. Véase Jesucristo liberador, pp. 264-270.

46. El famoso informe Rockefeller, escrito poco después de Medellín, dice que si se pone en práctica lo que alli dijeron los obispos, estarán en peligro los intereses de Estados Unidos. Esto no tiene mucho sentido a nivel militar y estralégico, pero sí lo tiene a nivel social: América Latina pone en peligro los valores del American way of life.

47. Véase Jesucristo liberador, pp.235-250.

48. La teorización e historización de la idolatría aparece, como hemos dicho, en la cuarta carta pastoral de Monsef̃or Romero, inspirada en Ellacurfa.

49. De Ellacuría se están publicando sus obras completas, sobre su pensamiento filos6fico y teológico se han publicado ya varios art́culos y se están escribiendo tesis doctorales, se ha hecho una obra de teatro y se está filmando una pelicula.

50. "Monsefior Romero...", p. 10. 